\title{
KUASA BAHASA DALAM WACANA PERKULIAHAN
}

\section{LANGUAGE POWER IN LECTURE DISCOURSE}

\author{
Sultan, Akmaluddin \\ Universitas Islam Negeri Mataram \\ Ponsel: 085253372060; Pos-el: sultan@uinmataram.ac.id, akmal@uinmataram.ac.id
}

Naskah Diterima: 25 Juli 2019; Direvisi: 4 Desember 2019; Disetujui: 4 Desember 2019

DOI https://doi.org/10.26499/mab.v13i2.251

\begin{abstract}
Abstrak
Artikel ini bertujuan untuk mengkaji struktur bahasa, aspek-aspek situasi tutur, dan dimensi sosial yang terjadi dalam kuasa wacana perkuliahan di FSEI IAIN Pontianak. Pengumpulan data dilakukan dengan metode simak dengan teknik rekam. Metode simak digunakan atas dasar bahwa wacana baik tulisan maupun lisan adalah bentuk praktik sosial yang menyebabkan hubungan dialketis di antara peristiwa diskursif tertentu dengan situasi, institusi, dan struktur sosial yang membentuknya. Adapun analisis data dilakukan dengan metode padan ekstralingual dengan menghubungbandingkan hal-hal di luar bahasa yang terjadi pada wacana perkuliahan. Hasil penelitian ini adalah (1) Struktur bahasa yang membangun wacana perkuliahan di FSEI IAIN Pontianak adalah makro struktur, super struktur, dan mikro struktur; (2) Aspek-aspek situasi tutur kuasa bahasa dalam wacana perkuliahan di FSEI IAIN Pontianak dibangun oleh aspek penutur, lawan tutur, konteks tuturan, tujuan tuturan, tindak tutur, dan wacana perkuliahan sebagai produk tindak verbal; dan (3) Dimensi sosial yang terjadi dalam kuasa wacana interaksi dalam perkuliahan di FSEI IAIN Pontianak ditemukan sejumlah praktik sosial yaitu: praktik pemunculan otoritas dosen baik sebagai pengatur disiplin maupun sebagai pemberi materi, dominasi dosen di dalam perkuliahan, ketidakkonsistenan dosen dalam praktik prilakunya di depan perkuliahan
\end{abstract}

Kata kunci: kuasa bahasa; wacana perkuliahan

\begin{abstract}
This article is aimed at investigating language structures, aspects of speech situation, and social dimension that occur in the power of lecture discource in FSEI IAIN Pontianak. Data are collected from listening method and recording technique. Listening method is used in consideration that both written and spoken discource are forms of social practice cause dialectical relation between certain discourced phenomenom and situation, institutions, and social structure where they are used. While data analysis uses extralingual comparative method that compares nonlingual aspects found in lecture discource. Results of the research shows (1) language structure built the lecture discource at FSEI IAIN Pontianak are macro structure, super structure, and micro structure; (2) aspects of speech situation at FSEI IAIN Pontianak are formed by speaker aspects, listener, speech context, purpose of speech, speech act, and the lecture discource as the product of verbal act; (3) social dimension found in the lecture discource at FSEI IAIN Pontianak is social practice covering the authority of lecturer to rule either as discipline ruler or resource speaker, the lecturer dominance during the lecture, and lecturer inconsistance concerning their behavioral practice during the lecture itself.
\end{abstract}

Keywords: power of language; lecture discource 


\section{Pendahuluan}

Bahasa merupakan unsur utama di dalam proses realitas. Proses konstruksi realitas dimulai ketika seorang konstruktor melakukan objektivikasi terhadap suatu kenyataan yakni melakukan persepsi terhadap suatu objek. Selanjutnya, hasil dari pemaknaan melalui persepsi itu diinternalisasikan ke dalam diri seorang konstruktor. Dalam tahap itulah dilakukan konseptualisasi terhadap suatu objek yang dipersepsi. Langkah terakhir adalah melakukan eksternalisasi atas hasil dari proses perenungan secara internal tadi melalui pernyataan-pernyataan. Alat untuk membuat pernyataan tersebut tiada lain adalah kata-kata suatu konsep atau bahasa.

Bahasa yang digunakan setiap orang dalam kehidupan tentu tidak terlepas dari konteks pembicaraanya. Dengan kata lain bahwa bahasa berkaitan erat dengan bidang lain misalnya sosial, budaya, dan pendidikan. Dalam hal ini, Purnomo (2017) menyatakan bahwa bahasa dipelajari sebagai suatu proses sosial yang membentuk budaya, karenanya bahasa tidak mungkin dikaji lepas dari faktor sosial budaya yang berlaku.

Definisi tersebut memuat pernyataan bahwa bahasa memiliki fungsi sosial, pemersatu masyarakat, sekaligus pengonstruksi budaya, dan memengaruhi orang lain dengan kuasa bahasa. Hanya dengan bahasa orang dalam kelompok sosial tertentu dapat berinteraksi, dan mengembangkan perilaku hidupnya. Bahasa bukan hanya alat berperilaku, melainkan pembentuk perilaku. Sebagai ilustrasi sederhana, seorang pengendara motor segera turun dari motor dan mematikan mesin kendaraanya, ketika sampai di depan gang yang bertuliskan "Masuk gang turun dari kendaraan dan matikan mesin." Inilah wujud dari kuasa bahasa yang mampu merubah tindakan dan perilaku dalam komunitas interaksi sosial.

Hasil dari produksi ucapan yang dikemukan oleh penutur/penulis kepada lawan tutur/pembacanya akan membentuk wacana. Salah satu tipe analisis wacana lisan adalah wacana interaksi dalam perkuliahan. Analisis wacana interaksi dalam perkuliahan berbeda dengan analisis wacana lisan yang lain, seperti wawancara ataupun sejenisnya. Dalam wacana interaksi perkuliahan, terdapat interaksi antara dosen dan mahasiswa dan antara mahasiswa dengan dosen. Dalam konteks ini, wacana interaksi perkuliahan dapat dikaji dan ditafsiri berdasarkan kondisi lingkungan sosial yang melandasinya.

Penelitian yang mengangkat topik kuasa bahasa pernah dilakukan peneliti lain, misalnya Khak (2015) yang mengangkat topik Formula Kuasa dalam Bahasa Surat Kabar: Analisis Dimensi 
Mikro AWK Model Fairclough. Kajian terhadap kuasa bahasa lisan dalam interaksi kelas merupakan kajian wacana. Dalam penelitian ini, dilakukan analisis terhadap bahasa lisan dalam interaksi perkuliahan di kelas bertujuan untuk melihat dimensi struktur bahasa yang membangun wacana, dan mendeskripsikan aspek-aspek situasi tutur dalam wacana perkuliahan, dan dimensi sisoal yang terdapat dalam wacana perkuliahan di FSEI IAIN Pontianak. Paparan-paparan di atas menjadi dasar permasalah dalam penelitian ini.

Pada hakikatnya, perilaku komunikasi dosen dalam peroses perkuliahan bersama mahasiswanya merupakan refleksi dari ideologi yang dianutnya, dengan melihat perilaku komunikasi dosen dalam bertindak di dalam kelas akan tergambar pola dosen memandang posisi komunikasi mahasiswanya. Apakah dosen memandang mahasiswa berdasarkan konsep bawahanatasan? Ataukah berdasarkan konsep bahwa dosen merupakan motivator dan fasilitator serta mitra dalam perkuliahan. Hal ini merupakan realisasi dari sistem pikiran dan kepercayaan yang ada pada individu dosen.

Kajian tehadap kuasa bahasa dalam wacana perkuliahan merupakan penerapan analisis wacana dengan perspektif interdispliner. Analisis wacana kritis berkorelasi dengan tinjauan ideologi.
Menurut pandangan ini hubungan kekuasaan dalam masyarakat dibarengi oleh bahasa hegemoni dengan menyatakan realitas di balik ideologi.

Fairclough (1992:9) mengatakan bahwa penggunaan bahasa ditentukan secara sosial. Penggunaan bahasa memiliki pengaruh terhadap masyarakat dan juga ditentukan oleh masyarakat. Dengan demikian, hubungan yang terjadi bersifat dialektik atau dua arah. Hubungan dua arah ini direalisasikan dengan hubungan antara ketiga dimensi sosial dengan ketiga fungsi utama bahasa. Ketiga dimensi sosial tersebut adalah pengetahuan, hubungan sosial, dan identitas sosial. Ketiga dimensi ini masing-masing berhubungan dengan fungsi utama bahasa yang berupa fungsi gagasan (ideasional) fungsi hubungan (relasional) dan fungsi identitas. Dari jalinan hubungan tersebut, tampak bahwa sebagai salah satu bentuk wacana, teks tidak hanya dibangun oleh faktor linguistik, melainkan juga faktor sosial yang dalam hal ini faktor ekstralinguistik. Oleh sebab itu, penelitian ini merupakan kajian analisis wacana kritis yang menerapkan perspektif interdispliner. Hal ini dilakukan untuk melihat dominasi kuasa bahasa komunkasi antara dosen dan mahasiswa dalam perkuliahan. 


\section{Landasan Teori}

\subsection{Kuasa Bahasa}

Dalam kajian sosiolinguistik, bahasa dipelajari sebagai suatu proses sosial yang membentuk budaya, karenanya bahasa tidak mungkin dikaji lepas darifaktor sosial budaya yang berlaku pada saat itu. Bahasa bukanlah melulu alat komunikasi yang steril, melainkan juga untuk menunjukkan identitas sosial budaya, untuk memelihara hubungan sosial budaya dan acapkali merupakan peristiwa sosial budaya.

Realitas yang terjadi di masyarakat menunjukkan adanya perbedaan antara idealitas dan realitas. Idealitas yang sesungguhnya merupakan bentuk sebenarnya dalam penggunaan bahasa di masyarakat sering mengalami collaps position (posisi yang salah arah). Sering ditemukan penyalahgunaan fungsi bahasa yang di masyarakat. Kalimat-kalimat seperti "hanya anjing yang kencing di sini”, "Tikus kantor seharusnya dibunuh", merupakan kalimat yang ditujukan untuk manusia akan tetapi menggunakan hewan sebagai representasi.

Hal ini tentunya mengalami disfungsi kalimat, namun anehnya hal semacam ini seakan sudah layak digunakan di masyarakat dan dianggap sebagai sesuatu yang lumrah. Ini tentunya berbahaya apabila digunakan secara terus menerus.
Masyarakat akan kehilangan kearifan berbahasa manakala kalimat-kalimat tersebut masih digunakan.

\subsection{Wacana}

Analisis wacana perkuliahan dalam penelitian ini adalah sebuah upaya atau proses (penguraian untuk memberikan penjelasan dari sebuah teks (realitas sosial) yang diproduksi oleh dosen yang kecenderungannya mempunyai tujuan tertentu untuk memperoleh apa yang diinginkan (Darma, 2009). Pemikiran tentang analisis wacana perkuliahan dalam penelitian ini menitikberatkan pada representasi, relasi, dan identitas. Fungsi representasi berkaitan dengan cara-cara yang dilakukan untuk menampilkan realitas sosial ke dalam bentuk teks.

Fairclough (dalam Eriyanto, 2011:285) berpendapat bahwa analisis wacana kritis adalah, bagaimana bahasa menyebabkan kelompok sosial yang ada bertarung dan mengajukan ideologinya masing-masing. Konsep ini mengasumsikan bahwa praktik wacana bisa jadi menampilkan efek sebuah kepercayaan (ideologis) artinya wacana dapat memproduksi hubungan kekuasaan yang tidak imbang antara kelas sosial, laki-laki dan wanita, kelompok mayoritas dan minoritas. Analisis wacana melihat pemakaian bahasa tutur dan tulisan sebagai praktek sosial. Praktek sosial dalam 
analisis wacana dipandang menyebabkan hubungan yang saling berkaitan antara peristiwa yang bersifat melepaskan diri dari sebuah realitas, dan struktur sosial.

Fairclough (1995) mengklasifikasikan sebuah makna dalam analisis wacana sebagai berikut:

a. Translation (mengemukakan subtansi yang sama dengan media).

b. Interpreatation (berpegang pada materi yang ada, dicari latarbelakang, konteks agar dapat dikemukakan konsep yang lebih jelas).

c. Ekstrapolasi (menekankan pada daya pikir untuk menangkap hal dibalik yang tersajikan).

d. Meaning (lebih jauh dari interpretasi dengan kemampuan integratif, yaitu inderawi, daya pikir dan akal budi).

Selain klasifikasi makna dalam analisis wacana kritis, Fairclough (1995) juga memberikan tingkatan dalam analisis wacana yaitu sebagai berikut:

a. Analisis Mikro Struktur (Proses produksi): menganalisis teks dengan cermat dan fokus supaya dapat memperoleh data yang dapat menggambarkan representasi teks.

b. Analisis Meso Struktur (Proses interpretasi): terfokus pada dua aspek yaitu produksi teks dan konsumsi teks. c. Analisis Makro Struktur (Proses wacana) terfokus pada fenomena dimana teks dibuat.

Dengan demikian, menurut Fairclough untuk memahami wacana (naskah/teks) kita tak dapat melepaskan dari konteksnya. Untuk menemukan "realitas" di balik teks diperlukan penelusuran atas konteks produksi teks, konsumsi teks, dan aspek sosial budaya yang memengaruhi pembuatan teks (Eriyanto, 2011: 286).

\section{Metode Penelitian}

\subsection{Pendekatan Penelitian}

Pendekatan yang digunakan dalam penelitian ini adalah pendekatan kualitatif deskriptif karena penelitian ini bertujuan untuk memberikan gambaran atau deskripsi tentang suatu keadaan secara objektif. Namun demikian, penelitian ini tidak terbatas pada deskripsi kuasa bahasa dalam wacana perkuliahan, melainkan dilakukan pula analisis teks wacana perkuliahan untuk menemukan model kuasa bahasa terjadi dalam konteks perkuliahan. Sumber data dalam penelitian ini adalah penggunaan bahasa lisan pada konteks perkuliahan yaitu bahasa yang digunakan oleh dosen dan mahasiswa dalam interaksi perkuliahan.

\subsection{Populasi Penelitian}

Populasi dalam penelitian ini adalah pengunaan bahasa lisan dalam konteks 
perkuliahan pada Fakultas Syariah dan Ekonomi Islam IAIN Pontianak. Dalam konteks perkuliahan, penggunaan bahasa lisan tentu sangat banyak sehingga perlu dilakukan pembatasan terhadap populasi penelitian ini (sampling).

\subsection{Sampel Penelitian}

Teknik sampling yang digunakan dalam penelitian ini adalah purposive sampling yaitu teknik penentuan sampel dengan diidentifikasi terlebih dahulu. Dalam hal ini sampel yang dimaksud adalah penggunaan bahasa lisan oleh dosen kepada mahasiswa pada konteks perkuliahan pada Mata Kuliah Islam dan Budaya Lokal, Amsilati, Usul Fiqih, dan Metodologi Studi Islam. Pemilihan mata kuliah ini didasarkan pada realita bahwa situasi perkuliahannya lebih interaktif sehingga memungkinkan penggalian data yang lebih banyak dan relevan dengan konteks penelitian.

\subsection{Jenis dan Wujud Data}

Kategori data dalam penelitian ini adalah bahasa lisan yang digunakan oleh beberapa dosen di FSEI IAIN Pontianak. Sedangkan wujud datanya adalah kalimatkalimat yang digunakan dosen yang memiliki kecenderungan memperlihatkan kuasa bahasa.

\subsection{Pengumpulan Data}

Pengumpulan data dalam penelitian ini dilakukan dengan metode simak dengan teknik rekam. Perekaman bahasa lisan dilakukan saat perkuliahan berlangsung di 4 jurusan yang ada di FSEI IAIN Pontianak. Dalam perekaman, peneliti mengambil satu kelas dan satu aktivitas perkuliahan pada masing-masing jurusan. Hal ini berdasarkan objek penelitianya bahasa lisan maka peneliti mempertimbangkan efesiensi waktu dalam mentranskripsi hasil rekaman tersebut.

\subsection{Analisis Data}

Analisis data dilakukan dengan metode padan ekstralingual. Metode padan ekstralingual ini digunakan untuk menganalisis unsur yang bersifat ekstralingual, seperti menghubungkan masalah bahasa dengan hal yang berada di luar bahasa. Dalam hal ini, unsur luar bahasa yang dimaksud misalnya peran dosen dan mahasiswa, aspek perbedaan tingkat wawasan dosen dan mahasiswa, dan perbedaan usia dosen dan mahasiswa.

\section{Pembahasan}

\subsection{Struktur Bahasa yang Membangun Wacana Perkuliahan di FSEI IAIN Pontianak}

Wacana perkuliahan pada lokasi penelitian dibangun dengan tiga komponen struktur, pertama struktur makro, kedua superstruktur, dan ketiga mikro struktur. Lebih terprincinya, peneliti menguraikan model-model struktur kuasa bahasa dalam wacana perkuliahan. 


\section{a. Struktur Makro}

Struktur makro merupakan struktur global/umum dari suatu teks yang dapat diamati dengan melihat setiap komunikasi akan diawali dengan struktur makro. Bentuk tuturan selalu dilatarbelakangi oleh maksud dan tujuan tertentu. Hal inilah yang menyebabkan suatu tuturan akan berbeda dengan tuturan lainnya. Mengacu pada penjelasan di atas, maka tujuan hadirnya tuturan dalam konteks perkuliahan ini adalah untuk memberikan pengetahuan, informasi, ruang berdiskusi menyangkut materi perkuliahan yang telah terprogram. Dari data yang penelti dapatkan terdapat beberapa tujuan tuturan dalam wacana perkuliahan, diantaranya

a. Menyampaikan penjelasan gagasan dan pengetahuan masing-masing (penutur dan lawan tutur).

Tujuan utama tuturan dalam wacana perkuliahan ini adalah untuk menyampaikan gagasan dan pengetahuan masing-masing baik antara penutur dan lawan tutur, yang menyangkut materi yang telah diagendakan. Hal ini tergambar pada masing-masing data, dari awal sampai akhir komunikasi. Lebih jelas dapat dilihat pada penggalan wacana berikut.

\section{(1)}

Kita adalah makhluk sosial satu dengan yang lainya saling membutuhkan tersebut ke dalam keadaan yang diinginkan dan yang tidak diinginkan. Titik temu antara I'tikah dengan fiqih itu, dimana letaknya? Fiqih adalah salah satu dari illmu yng terbatas antara dari semua Fuqaha. Kita sebagai umat Islam yang sama-sama mencintai Allah dan Rasulnya, dan apabila kita ingin mendapatkan hal yang baik kepada Allah swt kita harus mengetahui semua aturan yang tidak sesuai dengan ajarannya. Pada intinya I'tikah adalah penyempurnaan bagi fiqih. Karakter ilmu fiqih kita sebagai manusia berarti kita mempunyai karakter, akan tetapi ada pernyataan yang terdapat ke dalam riferensi yang berkaitan dengan karakter dan keistimewaan ilmi fiqih.

Beberapa filsafat misalnya, kalau dalam teologi itu ada 4, bahwa Islam itu hanya menyempurnakan manusia. Jadi, tanpa Al-Qur'an pun manusia sebenarnya sudah bisa berfikir mana yang baik dan mana buruk, akhirnya mereka juga mengakui bahwa manusia mempunyai kelemahan sehingga wajar saja ada kewajiban untuk memberikan kesempurnaan kepada manusia, tetapi bagi yang ada petunjuk saja menyusahkan bagaimana kalau tidak dikasih petunjuk. Kalau dalam setiap agama itu ada perpecahan/aliran (firqah). Jadi, tidak usah membahas agama orang lain. Ada macam Injil Mautus dan macam-macam injil yang lainnya, boleh berkomentar tapi pahami dulu ilmunya. Jangan hanya berbicara katanya-katanya saja, tau-taunya membohongi orang lain.

Dalam Islam saja banyak sekali perpecahan antarsesama agama, apa lagi luar agama Islam. Dalam Islam saja mulai dai 0 bulan sampai akhil baligh, berbuat apa pun tidak diberi dosa dan juga tidak diberi pahala. Tetapi Anda kalau sudah akil balig, wajib hukumnya menegakkan apa yang sudah diperintahkan dan menjauhi apa yang dilarangnya. Kenapa manusia perlu agama? 
Karena manusia mempunyai kelemahan dan kekurangan.

Inna dan kawan-kawannya banyak, eh kana dan saudaranye, kaanna ape lagi di sini ade ndak usah ditulis la, di mane ada di buku yang kecil ni di buku yang kecil di rangkuman, ahh mane die saye pun tak tau, no 53. Kana amalnya merofakan muttada' menjadi isimnya dan menashobkan khobarnya menjadi khobarnya, khobarnya kanna saudara kanna yang khobarnya sama kanna zhola bata adha absaha khamsya soroh larisa zhala bai'a. Ya itu ya mil, ok udh terjawab, makenye ini ni meman harus kalian bace di mane-mane harus bawa sengaje dibuat kecil supaye bise, ini kesimpulan kalian.

laisa laisa itu hal 15 laisa itu merofakan mubtada' menjadi isimnya laisa dan menashobkan khobar menjaid khobarnya laisa, artinya laisa sama juga fungsinya dengan kanna beda diawali huruf jer atau dengan bahse lain, khobarnya laisaa ni yaa khobar mesti pakek huruf jer kalaw kanna tu kan tak mesti tpakek huruf jer laissa pasti pakek huruf jer sehingga tak nampak ade kalimat dibaca nashob, contoh alaisa allahu bikafil abdahu, alaisanya allhu menjadi khobarnya.

Materi hari ini adalah teknik penulisan karya ilmiah, dan cara mengambil data dalam penulisan dari responden. Responden, gak masalah $k k$ mw makai yang responden. Tapi bagaimana kita merangkum bahwa itu benar" tertarik gitu lo bukan cuman kita yang tertarik dengan hal itu tetapi orang lain yang membaca juga tertarik. Jadi, itulah bungkusan" dalam pendahuluan. Terus bagaimana kita merangkum fokus penelitian. Fokus penelitan itu gampang. Kita melihat saja situasi yang ada $d$ ilapangan. Lihat hal" apa yg akan kita gali di sana. Tulis saja di situ apa, bagaimana, siapa kapan dan sebagainya. Mulailah kalimat" tanya itu terus kalau seandainya fokus penelitian ada makna ja itu cuman diubah saja, tidak pakai bagai tidak pakai pertanyaan cukup situasi adil, fiqih terakhir kalau fokus katanya dan sebagainya itu suara seting boleh dibacalah sesuai dengan penelitian apakah kualitatif atau kuantitatif tergantung atau penelitian komperatih yang gabungan antara dua penelitian. Ada penelitian yang tidak bisa di selesaikan dengan kuantitatif yang Cuma menggambarkan/mendeskripsikan tidak bisa harus ada data tabel daftar himpunan maka dia kita komperatifkan kita gabungkan penelitian kualitatif dan kuantitatif boleh ada bukunya julia s bandung metodologi penelitian komperatif menggabungkan dua terus biasakan dalam daftar pustaka kajian pustaka cari dulu penelitian penelitian terdahulu yang sama atau yang mirip dengan penelitian kita yang beda $d$ lokasi cari di skripsi ada tidak yang sama tulis situ. Penelitia A seperti ini terus $B$ nya ngomomg apa terus anda di sini posisi Anda yang membedakan antara A, B dan C Anda itu walaupun sama dalam penelitian tapi Anda itu berbeda antara $a$ dan $b$ itu yang paling penting Anda berbeda dengan a Anda berbeda dengan c boleh judul sama kemampuan ekonomi masyarakat bengkayang yang satunya kemampuan ekonomi masyarakat sintang boleh sama judulnya tapi fokus pasti beda terus beda antara a dan bitu.

Data-data di atas bertujuan untuk memberikan penjelasan dan informasi tentang pengetahuan kepada lawan bicaranya. 
b. Menyampaikan saran dan nasihat.

Tujuan kedua dari tuturan dalam wacana perkulihan ini adalah memberikan saran dan nasihat-nasihat yang bernuansa mativasi kepada lawan bicaranya (mahasiswa). Setiap tindak tutur dalam berkomunikasi akan ada tujuan-tujuan tertentu yang dikehendaki oleh penuturnya, karena tidak ada bahasa yang sunyi dari maksud. Adapun tujuan kedua dari tuturan dalam wacana perkuliahan adalah untuk menyampaikan saran dan nasihat. Hal ini seperti yang terdapat dalam penggalan wacana berikut.

Pesannya, beragamalah sebagaimana tuntunan, jangan riya, jangan menilai/mengolok-olok dan jangan mengejek orang lain atas dasar agama.

\section{b. Super Struktur}

Superstruktur merupakan struktur wacana yang berhubungan dengan kerangka suatu teks, bagaimana bagianbagian teks tersusun. Berikut berikut akan diperincikan.

\section{1) Pembukaan}

Dari sudut pandang mikro linguistik, struktur wacana perkuliahan ini dibentuk dari beberapa bagian. Selayaknya dalam sebuah komunikasi formal, komunikasi ini diawali dengan salam sebagai bagian struktur pendahuluan dalam wacana perkuliahan. Hal ini terdapat dalam penggalan wacana perkuliahan berikut ini.
D: "Asalamaualaikum warrahmatullah wabarkatuh"

M:"waalaikumsalam waramatullah wabarkatuh"

D: "Terimakasih atas kehadirannya, kita ketmu lagi dalam perkuliahan islam dan budaya lokal"

D:"Asalamuaalikum warahmatullah
wabarakatuh"

M:"Walaikumsalam warahmatullah wabaraokatuh"

D:"Baik, adik-adikku sayang. Sebelum berlangsung diskusi kita, kita buka perkuliahan ini dengan sama-sama melafalkan basmalah. Silahkan kelompok untuk menyiapkan diskusinya"

D: "Asalamualikum warahmatullah wabarakatuh, selamat sore dan salam sejahtera untuk kita semua"

M: "Walaikumussalam warah matullahwabarakatuh"

D: "Apa kabar anda sekalian?"

M:"Baik pak. Bapak, gimana kabarnya?"

D: "Baik. Seperti yang anda liat. Baik, silahkan dipersiapkan diskusi kita, kelompok siapa yang maju hari ini, silahkan maju"

D:"Asalamualikumwarahmatullahwabaro katuh"

M: "Walaikumssalam"

D: "Apa kabar saudara skalian?"

M: "Alhamdulilah. Baik pak"

D:" Terimakasih, kita masuk pada materi amsilati, sampai apa materi kita?"

Berdasarkan pengamatan dan hasil rekaman peneliti, pada bagian awal komunikasi, dosen mengawali komunikasi wacana dengan mengucapkan salam kepada mahasiswa, yang kemudian diikuti 
dengan jawaban salam secara serentak oleh mahasiswa. Hal ini bertujuan untuk membuka sekaligus menghangatkan komunikasi dalam berinteraksi dengan mahasiswa sebagai audiensi dalam perkuliahan. Dari pengamatan peneliti, setiap dosen selalu mengawali pembukaan komunikasinya dengan pengucapan salam. Setelah mengucapkan salam, dosen pun melanjutkan komunikasinya dengan menyampaikan ucapan terima kasih kepada mahamahasiswa. Hal ini bertujuan untuk membangun keakraban (friendly) dengan mahasiswa. Sebenarnya, jika dilihat dari teks ungkapan, terima kasih dikemukakan sebagai bentuk ucapan atas sebuah tindakan, namun dalam konteks ini mahahasiswa sebagai audiensi tidak melakukan apa-apa, namun diberikan ucapan terimakasih.

Bagian pembuka/pendahuluan secara super struktur berfungsi membuka komunikasi dalam perkuliahan. Hal ini bertujuan, bahwa secara etika komunikasi, sebuah percakapan idealnya dimulai dengan pengucapan salam. Model salam yang digunakan adalah salam sesusai dengan tradisi Islam. Hal ini disebabkan antara penutur (dosen) dan lawan tutur (mahasiswa) sama-sama beragama Islam. Jadi, penutur (dosen) yang menggunakan salam sejahtera. Pada bagian pembuka ini, terjadi interaksi antara dosen dan mahasiswa. Hal ini terwujud melalui jawaban salam yang diucapkan oleh mahasiswa sebagai lawan tuturnya.

Pada data (7) terdapat panggilan/kata sapaan "Sayang" yang digunakan oleh dosen kepada mahasiswa. Hal ini menjadi ungkapan yang menarik karena tiap-tiap dosen memiliki karakter dan gaya komunikasi yang khas dalam menyapa mahasiswa. Ungkapan ini dikemukakan untuk membangun keakraban dengan mahasiswa sehingga berdampak pada keharmonisan dan keakraban serta suasana kelas menjadi lebih santai. Dengan kondisi seperti ini, mahasiswa tidak merasa tertekan selama mengikuti perkuliahan. Penggunaan ungkapan sayang ini merupakan representasi dari kuasa simbolik, bentuk penguasaan secara terselubung. Dalam posisi inilah terlihat adanya kuasa bahasa.

\section{2) Isi (conten)}

Pada data (6), isi komunikasinya menjelaskan tentang topik perkuliahan. Topik yang dibahas adalah penulisan karya ilmiah. Dosen menjelaskan teknik-teknik menulis karya ilmiah dengan mendetail. Namun dilihat dari model komunikasinya, seolah-olah dosen hanya menjadi pembicara tunggal yang tidak memberikan waktu bagi mahasiswa untuk mengungkapakan gagasan-gagasan yang mereka miliki, sehingga dalam konteks ini 
komunikasi dalam wacana perkuliahan ini, hanya berjalan satu arah. Secara konsep kebahasaan, karena komunikasi ini adalah komunikasi lisan, seyogyanya dosen memberikan ruang berdiskusi bagi mahasiswanya sehingga tidak terjadi dominasi kuasa dalam berwacana pada komunikasi perkuliahan.

Pada data (6), struktur bahasa dengan kontennya tidak sinkron. Tema yang dibahas adalah tentang Islam dan Budaya Lokal, namun penjelasan dari awal komunikasi sampai isi yang disampaikan adalah teknik penulisan karya ilmiah dan teknik melakukan wawancara.

Pada data (7), konten yang dibicarakan antara dosen dan mahasiswa adalah tentang hukum Islam. Dilihat dari tema dan konten yang dibahas, bagian ini sangat koheren antara tema denga isi. Teknik penyampaian konten pada komunikasi ini adalah dengan pola diskusi. Pada data (7) ini, dosen hanya berperan sebagai mediator, adapun mahasiswa berdiskusi antarsesama sesuai dengan tema yang sudah ditentukan. Gaya komunikasi mahasiswa dalam menyampaikan konten wacananya terjadi pola dialog.

Diksi yang digunakan dalam penyampain isi/materi yang didiskusikan adalah kosa kata yang standar karena konteks komunikasinya adalah konteks formal. Dalam perwujudan keakraban, penggunaan pronominal jamak (kata kita) sering kali digunakan oleh mahasiswa. Hal ini bertujuan untuk membangun kesejajaran antarmereka dan keakraban untuk mereka. Kuasa bahasa dalam hal ini terlihat pada penguasaan ruang komunikasi yang didominasi oleh kuasa bahasa dosen. Seyogyanya, ruang komunikasi menjadi milik mahasiswa dan dosen secara berimbang.

Isi wacana pada data memperbincangkan pola beragama, merujuk pada makro strukturnya adalam metodologi studi islam, maka poin yang dibahas pada bagian konten ini adalah halhal yang menyangku tentang keagaaman. Fokus pembicaraannya pada data (8) adalah pola beragama.

Adapun pada data (9), antara makro struktur dengan superstruktur di bagian konten terdapat keselarasan. Artinya, konten wacananya sesuai dengan temanya. Oleh sebab itu, peneliti menyimpulkan bahwa data (9) terdapat keselarasan antara tema dengan konten dalam komunikasi wacana perkuliahan.

\section{3) Penutup}

Bagian penutup dalam komunikasi berfungsi untuk memberikan inti-inti dari sesuatu yang telah dijelaskan pada bagian kalimat sebelumnya. Dalam komunikasi wacana perkuliahan, bagian penutup ini dipergunakan untuk memberikan saran serta nasihat dan motivasi kepada mahasiswa sebagai mitra tuturnya. Di 
ujung komunikasi pada bagian penutup,

penutur (dosen) mengakhiri komunikasinya dengan mengucapkan salam. Berikut data-data yang menunjukkan model dan gaya komunikasi penutup dalam komunikasi perkuliahan.

Demikianlah hal-hal yang harus diperhatikan. Terima kasih. Asalamuaikum warahmatullah wabarkatuh.

M : Walaikumusalam.

Pada data di atas, dosen menutup komunikasinya dengan model yang sederhana dan singkat tanpa melakukan reduksi terhadap materi-materi yang disampaikan. Kemudian komunikasinya ditutup dengan pengucapan salam.
D: "Silahkan moderator menutup diskusinya!"

M: "Baiklah. Terimakasih atas perhatian dan partisipasi kawan-kawan dalam diskusi ini. Dan mohon maaf atas segala kesalahn dalam diskusi ini. Dan kita tutup diskusi ini dengan mengucapkan alahmdulilah."

Pada data (11), terdapat perbedaan pola dalam menutup komunikasi dalam wacana perkuliahan. Dosen memerintahkan melalui kalimat imperatif agar moderator diskusi mengakhiri komunikasi perkuliahan kemudian diikuti dengan ucapan apresiasi, permohonan maaf, dan ucapan terimakasih kepada mahasiswa atas partisipasinya dalam mengikuti perkuliahan.

122 | Mabasan, Vol. 13, No. 2, Desember 2019, hlm. 111-136 p-ISSN: 2085-9554, e-ISSN: 2621-2005

D: "Kesimpulannya, setiap manusia itu memiliki selisih agama yang berbedabeda, memiliki ritualitas yang sama, tetapi mempunyai penilaian yang berbeda-beda. Pesannya, Beragamalah sebagaimana tuntunan, jangan riya, jangan menilai/mengolok-olok dan jangan mengejek orang lain."

Pada bagian simpulan wacana perkuliahan di atas, disampaikan dengan struktur kalimat deklaratif, kemudian diikuti dengan struktur kalimat imperatif. Penggunaan kalimat deklaratif ini menunjukkan adanya kuasa bahasa dosen yang lebih dominan daripada mahasiswa. Dalam redaksi imperatif tersebut, penutur menyarankan kepada lawan tuturnya, terkait esensi simpulan dari materi yang telah didiskusikan.

Asmaul usna ikut wajan fail semua ikut wajan failun semua, bukan dia ngikut wajan failun jika isimnya fail, kecuali asamaul-husna tertentu yang sifat tidak bisa dilakukan manusia alkholik itu manusi tidak bisa, tapi dengan samiun yang bisa mendengar, al-bari yang bisa melapangkan hanya Allah. Ada pertanyaan? Baik. Kalo tidak ada, kita tutup pertemuan ini dengan melafalkan hamdalah. Terimakasih. Assalamualaikum.

Model penutup wacana perkuliahan pada data (13) berbeda dengan data-data sebelumnya. Penutur mengakhiri komunikasi dengan redaksi pertanyaan. Karena tidak ada yang bertanya kepadanya, ia melanjutkan dengan 
mengambil simpulan pernyataan melalui ucapan terimakasih.

\section{c. Mikro Struktur}

Struktur mikro adalah bentuk dan makna wacana yang dapat diamati dari suatu teks yakni kata, kalimat, proposisi, anak kalimat, parafase, dan gambar. Mikro struktur wacana dalam perkuliahan dibentuk dari unsur-unsur internal bahasa. Berikut paparan tentang aspek mikro struktur dalam wacana perkuliahan di FSEI IAIN Pontianak.

\section{1) Pilihan kata}

Dalam sebuah komunikasi, penguasaan penggunaan kosa kata dengan tepat menjadi keharusan karena apabila sebuah gagasan tidak dapat terwakili melalui simbol kata, gagasan tersbut tidak dapat tersampaikan kepada lawan tutur/lawan bicaranya.

Berikut diuraikan tentang model pilihan kata dalam wacana perkuliahan di FSEI IAIN Pontianak.

a. Penggunaan pronomina: kita, anda, kalian, adik-adik.

Pronomina merupakan kata ganti yang dipergunakan dalam sapaan antara penutur dan lawan tuturnya. Dalam konteks komunikasi perkuliahan antara dosen dan mahasiswa akan menggunakan pronomina sebagai pengganti nama dalam saling menyapa. Pronomina yang digunakan oleh dosen saat perkuliahan berlangsung untuk menyapa mahasiswa adalah pronomina kita, anda, kalian.

Pronomina Kita digunakan oleh dosen dalam konteks pemberian saran. Namun jika dilihat dari sudut arti leksikalnya, pronomina kita mencakup antara pembicara dan lawan bicara (dosen dan mahasiswa). Kata kita digunakan dengan tujuan penyamaan antara dosen dan mahasiswa. Penggunaan pronomina ini terdapat penggalan wacana di bawah ini.

Agar kita yang hidup beragama tidak diangap sebagai agama turunan, maka beragamalah secara rasional.

Dalam konteks kalimatnya, kata kita digunakan dengan maksud pemberian saran bagi semua, baik pembicara dan lawan bicara. Sebagaimana uraian di atas penggunaan kata kita oleh dosen bertujuan untuk memposisikan diri setara dengan mahasiswa dalam hal menerima saran.

Pronomina Anda digunakan sebagai kata sapaan untuk mahasiswa secara keseluruhan. Data dalam komunikasi dosen dan mahasiswa menunjukkan dosen selalu menyapa lawan bicaranya dengan sapaan Anda. Hal ini dilakukan untuk memberikan penghormatan kepada lawan bicara. Selain kata Anda, persamaan katanya adalah kamu, dan engkau. Namun, kedua pronomina ini peneliti tidak menemukan dosen dalam komunikasi perkuliahan menggunakan kata-kata tersebut. Pronomina Anda memiliki tingkat Mabasan, Vol. 13, No. 2, Desember 2019, hlm. 111-136 p-ISSN: 2085-9554, e-ISSN: 2621-2005 | 123 
kesopanan dibandingkan dengan kata kamu atau pun kata Engkau. Oleh sebab itu, untuk memunculkan rasa kesopanan dosen kepada mahasiswa, kata Anda menjadi pronomina yang baik digunakan saat perkuliahan berlangsung.

Sebenarnya, jika dosen menggunakan pronomina kamu dan engkau bisa saja dilakukan, karena dosen sebagai pembicara memiliki peran yang lebih dominan dalam menyampaikan gagasannya melalui gaya basa yang dikehendakinya, namun pronomina yang dipilih adalah pronominan anda. Hal ini menggambarkan bahwa dosen memosisikan lawan bicaranya pada posisi yang sejajar. Penggunaan pronomina anda ini terdapat pada penggalan wacana berikut.

Ketika Anda sudah bisa memfungsikan akal dan pikiran kita. Biar Islam ini tidak hanya menjadi slogan-slogan yang indah-indah tapi kosong dalam pelaksanaan. Ada sebuah pertanyaan tentang Islam, Bagaimana jadinya kalau manusia hidup tanpa agama?Bagaimana Anda melihat manusia sekarang yang beragama ini?

Peneliti menemukan penggunaan pronomina adik-adik sebagai pronomina sapaan yang merujuk pada lawan bicara (mahasiswa). Kata Adik secara tekstual berarti saudara yang memiliki hubungan darah dan berposisi lebih kecil dengan lawan katanya kakak. Penggunaan kata adik untuk menyapa lawan bicaranya bertujuan untuk membangun keakraban dan kedekatan antara pembicara (dosen) dan lawan bicara (mahasiswa). Hal ini mempermudah komunikasi dan berharap agar materi yang disampaikan diperhatikan dengan seksama sehingga dapat dimengerti dengan benar. Penggunaan pronomina adik terdapat pada penggalan wacana berikut.

Adik-adikku sayang. Sebelum
berlangung diskusi kita, kita buka
perkuliahan ini dengan sama-sama
melafalkan basmalah.

\section{2) Ragam bahasa}

Dalam tuturan wacana perkuliahan ini terdapat penggunaan ragam bahasa formal dan non formal.

a. Ragam bahasa formal

Ragam bahasa formal adalah ragam bahasa yang mengikuti kaidah-kaidah kebahasaan yang benar, baik dari kebenaran struktur kata sampai struktur kalimat dan paragrafnya. Dalam konteks wacana perkuliahan ini, bahasa yang digunakan adalah ragam bahasa formal. Seperti yang terdapat dalam penggalam wacana berikut.

Beberapa filsafat misalnya, kalau dalam teologi itu ada 4, bahwa islam itu hanya menyempurnakan manusia. Jadi, tanpa alquran pun manusia sebenarnya sudah bisa berfikir mana yang baik dan mana buruk. Akhirnya mereka juga mengakui bahwa 
manusia mempunyai kelemahan sehingga wajar saja ada kewajiban untuk memberikan kesempurnaan kepada manusia, tetapi bagi yang ada petunjuk saja menyusahkan bagaimana kalau tidak dikasih petunjuk. Kalau dalam setiap agama itu ada perpecahan/aliran (firqah). Jadi, tidak usah membahas agama orang lain. Ada macam Injil mautus dan macam-macam injil yang lainnya. Boleh berkomentar tapi pahami dulu ilmunya. Jangan hanya berbicara katanya-katanya saja tau-taunya membohongi orang lain.

Mengingat, perkuliahan adalah aktivitas formal, maka menjadi keharusan bagi penutur untuk menggunakan bahasa dengan ragam formal, yakni bahasa yang mengikuti kaidah-kaidah yang telah ditetapkan.

b. Ragam bahasa nonformal

Dalam wacana perkuliahan ini, peneliti menemukan penggunaan ragam bahasa nonformal. Hal ini seperti yang terdapat pada penggalan wacan berikut.

Ok, buka halaman berikutnya, laisa pasti jernya, khobarnya pasti jer, berarti sama la pakkhusus saudara kanna, agak rewel itu laisa hanya laisa yang awalnya diawali huruf jer, ya kalaw selain laisa tidak berlaku zhona shorof, itu tidak sama dengan laisa kenape tak dibahas karne sma dengan kanna bise jadi ade huruf jer nya bise jadi tak ade huruf jernya, bise jadi lo yaa, tak bermakna berarti kannna tak ade huruf jernya tidak juga bise ade bise tadak pilihan, zhona.
Pada penggalan wacana di atas, dapat diindentifikasi bahwa penggunaan ragam bahasa nonformal dalam perkuliahan. Hal ini dipengaruhi oleh dialek penutur. Penutur adalah berlatar belakang suku Melayu sehingga bahasa yang digunakan adalah dialek Melayu Pontianak. Ini terbukti dengan adanya kata karne, ade, dan dalam frasa, tak ade, bise ade bise tadak. Ungkapan-ungkapan ini adalah ungkapan yang jamak dikemukakan oleh penutur bahasa Melayu dialek Pontianak. Kuasa bahasa pada data tersebut ditunjukkan dengan adanya otoritas penuh dosen dalam menggunakan bahasa termasuk unsur bahasa daerah dalam konteks situasi formal.

\subsection{Aspek-aspek situasi tutur kuasa bahasa dalam wacana perkuliahan di FSEI IAIN Pontianak}

Sebagai wujud konkret dari proses komunikasi, wacana perkuliahan terikat pula pada situasi tutur tertentu. Oleh karenanya, dalam memahami wacana haruslah mempertimbangkan konsep Leech (1993:19 - 20) tentang aspek-aspek situasi tuturnya yaitu (i) penutur (addresser), penerima tutur (receiver), dan sasaran tutur (addresse), (ii) konteks tuturan, (iii) tujuan tuturan, (iv) tuturan sebagai tindak verbal, (v) tuturan sebagai produk tindak verbal. 
1) Penutur

Dalam kontek komunikasi pada wacana perkuliahan, penuturnya adalah dosen dan mahasiswa. Keberlangsungan komunikasi tidak hanya searah namun terjadi pola yang dinamis. Tidak selamanya dosen menjadi penutur utama, terkadang ia akan menjadi petutur dari penutur yang terdiri dari mahasiswa, baik secara individual maupun secara kolektif. Hal ini menunjukkan bahwa komunikasi dalam ranah perkuliahan berjalan dengan dinamis dan tidak ada hegemoni meski tidak pada semua kelas. Artinya, tidak semua kelas yang peneliti observasi terjadi pola yang dinamis. Terdapat satu kelas yang terjadi monopoli peran sebagai penutur yang dilakukan oleh dosen. Dosen tidak memberikan ruang dan waktu yang luas bagi mahasiswanya untuk berperan sebagai penutur dalam wacana perkuliahan di FSEI. Agar lebih jelas, berikut penggalan wacana yang menggambarkan penuturnya.

Jadi, kalau kayak gini maksud saya kalau ketemu dengan kalimat seprti ini gampang ya, ada kanna make bahase gampangnye nanti kite ni harus ketemu dengan khobarnya kanna yang dibaca nashob. Kalau khobar kananya tu ada isim nakiro gampang, isim nakiro kalaw dibaca nashob pasti ada alifnya di akhir, ada alif yaa pasti dinashob.
Kata saya pada penggalan wacana di atas menggambarkan penuturnya. Pronominal saya menjadi pronomina pilihan dalam komunikasi perkuliahan karena konteks komunikasinya adalah kontek formal. Selain itu, data di atas menggambarkan posisi kuasa bahasa dosen lebih dominan dan pilihan kata yang digunakan terlihat lebih luas bahkan terkesan tidak memperhatikan kaidah keformalan berbahasa seperti penggunaan kata kayak gini, ketemu, gampang, dan penggunaan dialek daerah.

2) Lawan tutur

Adapun yang dimaksud dengan lawan tutur dalam wacana perkuliahan adalah mahasiswa yang menanggapi dan memahami ungkapan dari pembicaranya. Ragam komunikasi perkuliahan adalah menggunakan ragam bahasa lisan. Oleh sebab itu antara lawan tutur dengan penuturnya cendrung menggunakan bahasa langsung.

Hal ini tergambar pada data berikut

M: Mohon izin Bapak, dari uraian yang Bapak sampaikan ada beberapa hal yang belum kami pahami. Oleh karena itu, mohon kiranya Bapak berkenan menjelaskan kembali penggunaan inna dalam bahasa Arab

D: Tadi saye sudah paparkan tentang inna, tapi kamu tidak memperhatikan dengan serius. Kamu baca sendiri di modul yang saya berikan. 
Berdasarkan data di atas, dapat dilihat lawan tutur (mahasiswa) menggunakan bahasa standar namun direspon oleh penutur (dosen) dengan bahasa yang tidak standar. Hal ini membuktikan bahwa peran kuasa bahasa dosen selalu mendominasi dalam peristiwa tutur.

\section{3) Konteks tuturan}

Konteks tuturan kuasa bahasa dalam wacana perkuliahan tergambar pada uraian berikut.

\section{a. Konteks Budaya}

Bahasa dan budaya merupakan dua hal yang tidak bisa dipisahkan antara yang satu dengan yang lainnya. Oleh sebab itu, setiap komunikasi yang berlangsung akan terpengaruh dengan budaya masingmasing penutur. Keterpengaruhan itu bisa diidentifikasi dari hal-hal terkecil, seperti dialeg, pola pelafalan hrurf atau pun kata. Dalam wacana perkuliahan ini, peneliti menemukan konteks pengaruh budaya yang meyebabkan gaya bahasa penutur. Hal ini seperti yang terdapat dalam penggalan wacana berikut ini.

Saye ulangi yang kite pelajari. Ini tak ada tanda khusus. Berarti, fiil tak ada tandanya la pak, tak adda jdi ini hanya behubungan dnegan makna, perhatikan yang kita pelajari kita ikutin tanda mufrod hanya berhubungan dengan makna, isim fail bermakna orang atau sesutu yang me contoh kata kerja menulis maka isim failnya adalah orang yang menulis, isim faill itu orang yang me, isim maful berarti orang atau sesutu, isim maf'ulnya sesuatu yang ditulis, isim fail makna lainnya objek dan maf'ul makna lainnya subjek, eh tebalek yee isim fail mesti disebut subjek dan maf'ul disebuk objek, kalian berfikir make tau saye tebalek, masdar berarti pean contoh penulisan, untuk mengetahui itu isim fiil masdar, harus dibadingin dengan wazan adalah bentuk baku atau standar.

Dari penggalan wacana di atas, dapat diidentifikasi beberapa pola komunikasi yang dihadirkan oleh penutur dipengaruhi oleh budaya penuturnya. Dari penggunaan diksi, penutur cenderung menggunakan dialek melayu. Hal ini tampak pada kata, saye, kite, ade, tebalek, yang seharusnya diucapkan saya, kita, ada, dan terbalik. Kata-kata di atas merupakan pola pengucapan dialek Melayu. Oleh sebab itu, penutur tampaknya lebih mudah berkomunikasi dengan dialek-dialek Melayu, padahal dalam konteks yang formal seyogyanya menggunakan bahasa yang formal dan bahasa yang standar. Bahasa yang formal adalah bahasa yang sunyi dari dialek bahasa-bahasa daerah.

b. Konteks Hegemoni Tuturan

Hegemoni tuturan merupakan penguasaan informasi yang dihadirkan oleh panutur kepada lawan tuturnya. Hal ini bertujuan untuk meyakinkan lawan bicara terhadap pernytaan yang dikemukakan. Dalam wacana perkuliahan terdapat konteks hegemoni tuturan. Hal ini terdapat pada penggalan wacana brikut. 
(22)

Agar kita yang hidup beragama tidak diangap sebagai agama turunan, maka beragamalah secara rasional ketika anda sudah bisa mempungsikan akal dan pikiran kita. Biar islam ini tidak hanya menjadi selogan-selogan yang indah-indah tapi kosong dalam pelaksanaan. Ada sebuah pertanyaan tentang islam, Bagaimana jadinya kalau manusia hidup tanpa agama?dan bagaimana anda melihat manusia sekarang yang beragama ini?

Yang beragama saja masih bisa menyimpang dari agamanya apa lagi yang tidak beragama, tuhan sudah memberikan petunjuk,sudah berikan undang-undang dan Tuhan sudah memberikan aturan mana yang baik dan mana buruk bahkan untuk berbuat sebagaiana yang tuhan tunjukan dalam Al'Quran tersebut bahkan kita diberinya pahala,dan apabila pahala kita sudah cukup nanti akan ada surga. Tapi, pelaksanaannya apa,masih banyak yang nyabung ayam, main togel. Jadi, beragama saja masih seperti ini, yang sudah jelas ada petunjuknya saja masih menyimpang, apa lagi tidak beragama dan tidak punya petunjuk.

Pada penggalan wacan di atas, terdapat konteks hegemoni oleh penutur kepada lawan tuturnya. Hal ini tampak pada redaksi kalimat yang dikonstruksi dengan pola kalimat imperatif. Penutur seolah-olah menyararankan dan memerintahkan, seperti kalimat beragamalah secara rasional ketika Anda sudah bisa mempungsikan akal dan pikiran kita. Kemudian pada bagian berikutnya, terdapat redaksi pertanyaan yang dikemukakan oleh penuturnya, seolah-oleh ia (penutur) bertanya, tetapi pertanyaan itu dijawab sendiri oleh penuturnya. Lawan bicara tidak diberikan kesempatan untuk meberikan jawaban atas pertanyaan yang dihadirkannya, seperti Bagaimana jadinya kalau manusia hidup tanpa agama? dan bagaimana Anda melihat manusia sekarang yang beragama ini? Kalimat ini seakan-akan meminta jawaban, tetapi dari konteksnya hanya bertujuan hegemoni agar lawan bicara meyakini terhadap informasi atau gagasan yang disampaikan oleh penutur.

c. Wacana perkuliahan sebagai tindak tutur

Austin (1962:108) mengemukakan bahwa tindak tutur berkaitan dengan analisis ujaran dalam kaitannya dengan perilaku penutur suatu bahasa dengan lawan bicaranya. Tindak tutur ini merupakan aktivitas komunikasi (tindak lokusi) yang di dalamnya terkandung maksud yang ingin disampaikan pada saat berbicara (daya ilokusi suatu ujaran) dan efek yang ingin dicapai oleh penutur (perlokusi dari ujaran).

Searle di dalam bukunya Speech Act: An Essay in The Philosophy of Language (1969, 23--24) mengemukakan bahwa secara pragmatis setidaknya ada tiga jenis tindakan yang dapat diwujudkan oleh seorang penutur, yakni tindak lokusi, tindak ilokusi, dan tindak perlokusi.

128 | Mabasan, Vol. 13, No. 2, Desember 2019, hlm. 111-136 p-ISSN: 2085-9554, e-ISSN: 2621-2005 
Tindak lokusi adalah tindak tutur untuk menyatakan sesuatu. Tindak tutur ini disebut sebagai the act of saying something. Tindak ilokusi adalah tindak tutur yang selain berfungsi menginformasikan sesuatu dapat juga dipergunakan untuk melakukan sesuatu. Tindak ilokusi ini disebut sebagai the act of doing something. Terakhir, tindak perlokusi adalah tindak tutur yang pengutaraannya dimaksudkan untuk mempengaruhi lawan tutur. Tindak tutur ini disebut the act of affecting some one. Inti dari tindak tutur adalah tindak ilokusi karena dalam mengatakan sesuatu si penutur juga melakukan sesuatu. (Searle, 1979:1 dalam Schiffrin, 1994:57).

Dari 4 situasi tuturan dalam wacana perkuliahan, peneliti mendapatkan 2 situasi tuturan itu berlangsung dengan model diskusi dan 2 situasi tuturan dilakukan dalam konteks peyampaian informasi tunggal atau cendrung situasi tuturan berlangsung satu arah.

Tindak tutur lokusi pada wacana perkuliahan tersebut terlihat pada tuturan yang disampaikan oleh penutur (dosen) berupa tuturan yang mengandung berita atau informasi tentang pengetahuan. Kemudian dari tuturan yang mengandung informasi mereka (mahasiawa) menindak lanjuti dengan bertanya kepada penutur atas haal yang belum dapat dipahami. Adanya tindakan untuk melakukan sesuatu atau ilokusi yang berupa bertanya dan melakukan pembatahan atas informasi yang diterima merupakan tindakan ilokusi. Dari tindak lokusi dan ilokusi tersebut, muncul efek terhadap petutur yang disebut sebagai tindak perlokusi.

Selain itu, tindak tutur langsung dan tidak langsung juga terdapat dalam wacana tuntutan tersebut. Tindak tutur langsung tampak pada tuturan yang disampaikan secara langsung dengan menggunakan modus kalimat berita, kalimat tanya, dan kalimat perintah. Ketiga jenis kalimat tersebut digunakan secara konvensional sesuai dengan fungsinya. Sedangkan tindak tutur tidak langsung, terlihat pada penggunaan kalimat berita dan kalimat tanya untuk memerintah agar petutur tidak merasa diperintah.

\section{d. Wacana perkuliahan Sebagai Produk Tindak Verbal}

Leech (1983:14) mengatakan bahwa selain sebagai tindak ujar atau tindak verbal dalam pragmatik, kata 'tuturan' dapat digunakan sebagai produk suatu tindak verbal (bukan tindak verbal itu sendiri). Wujud tuturan yang dituturkan oleh penuturnya itu disebut sebagai produk dari tindak verbal. Dalam hal ini, tuturan dimaknai secara pragmatik sehingga terikat oleh situasi tertentu. Situasi tersebut mencakup penutur, petutur, tujuan tuturan, konteks tuturan, tujuan tuturan, tuturan sebagai bentuk tindakan, tuturan sebagai 
tindak verbal. Kelima hal tersebut, merupakan syarat dalam mengkaji suatu tuturan, karena setiap tuturan tidak lepas dari konteks dan situasi yang melingkupinya.

e. Dimensi sosial yang terjadi dalam kuasa wacana interaksi dalam perkuliahan di FSEI IAIN Pontianak

Berikut uraian tentang dimensi sosial yang terjadi dalam kuasa bahasa wacana perkiliahan di FSEI IAIN Pontianak. Penganalisisan dirangkai dengan memaparkan ujran-ujaran dosen serta bentuk interaksi yang terjalin serta tindakan yang mendukung interaksi sosial tersebut.

Dalam pandangan tradisional, dosen adalah orang yang mengajarkan membagikan, memberikan, dan menyebarkan pengetahuan kepada mahasiswa. Dosen dianggap memiliki kelebihan daripada mahasiswa. Mahasiswa pun duduk secara pasif ketika dosen sedang berbicara atau menunjukan kebolehannya. Meja dan kursi disusun berbasis dan papan tulis diletakan di depan disusun berdasarkan peranan dosen. Gambaran fungsi dan peran dosen serta gambaran situasi kelas secara tradisional tersebut terjadi dan terdapat di FSEI IAIN Pontianak.

Dosen "konvensoinal" tersebut menjalankan agendanya sebagai pembuka proses perkuliahan dan menjadi pemimpin dalam proses perkuliahan. Dengan demikian, dosen memulai perkuliahan dengan menyampaikan salam yaitu "Asalamualaikum warahmatullah wabarakatuh. Apa kabar SaudaraSaudara, semuanya?" Mahasiswa sesuai dengan perilaku kelaziman dalam mayarakat menjawab salam pembuka tersebut dengan "Walaikumsalam, Pak. Alhamdulilah, baik." Praktik seperti ini berlaku dari waktu ke waktu dan telah menjadi rutinitas dari kegiatan kelas.

Selanjutnya dengan otoritasnya sebagai pengontrol kelas, dosen meminta mahasiswanya untuk meng-silent-kan hand phone (HP) agar tidak mengganggu kelancaran proses perkuliahan. Hal ini ditunjukan dosen dengan tuturan "mohon yang membawa HP untuk tidak menggunakannya selama perkuliahan berlangsung." Mahasiswa yang merasa memiliki HP dengan segera mematikan HP mereka masing-masing. Dosen mengiyakan tindakan mahasiswa dan melakukan persetujuan dengan menuturkan kata "Ya". Selanjutnya dosen sebagai institusi yang berwenang dalam memberikan materi perkuliahan mulai memperkenalkan topik. Dosen melakukan dengan strategi linguistik yang dapat membantunya memulai pelajaran. Dosen menyebutkan "Saudara masih ingat 
apa materi hari ini? Tolong dilihat di silabusnya!" Ujaran tersebut dilakukan oleh dosen untuk melibatkan mahasiswa dalam memulai topik yang akan dibahas pada waktu perkuliahan agar mahasiswa tahu apa yang akan dibicarakan oleh dosen dan mereka/ atau oleh kawan kelompok diskusi yang akan persentasi.

Dengan demikian, dosen mempersiapkan mahasiswa untuk melakukan tindakan selanjutnya yang dikehendaki oleh dosen. Hal ini merupakan aplikasi dari pemertahanan tatanan fungsi dan pesan dosen menurut konsep konvensional.

Dari pola giliran yang terdapat di dalam interaksi kelas ini, terlihat adanya dominasi dosen di dalam kelas. Pola pergiliran yang terdapat dalam perkuliahan tersebut ialah D-M-D-M-D-M-D-M-D-MD-M-D-M-D-M. Dapat dilihat adanya pergiliran yang dua arah yaitu dari dosen (D) ke mahasiswa (M), dosen ke mahasiswa demikian seterusnya. Hal ini menandakan pemicu utama perkuliahan adalah dosen baik sebagai pembuka perkuliahan, pembuka pertanyaan, maupun sebagai inisiator utama proses perkuliahan secara keseluruhan.

Dosen mengucapkan "Minggu lalu kitakan sudah membahas beberapa teori, ya?" Sementara itu, mahasiswa sebagai pengikut yang berada di belakang dosen mengikuti kemauan dan arah petunjuk. Mahasiswa cukup mengucapkan "Ya."

Selain mendominasi kelas dan menjadi penguasa kelas, dosen menjadi orang serba tahu. Hal ini terbukti dari prilakunya dengan mengajukan pertanyaan kepada mahasiswa. Dosen tidak sabar menunggu dalam hitungan beberapa detik lalu ia mengajukan pertanyaan kembali "Bagaimana?" Karena ada jawaban dari mahasiswa, akhirnya dosen menjawab dengan memberikan penjelasan kepada mahasiswa. Dengan demikian, selesai sudah dosen menunjukan kemampuannya dalam mengajukan pertanyaan sekaligus menjawab pertanyaan itu sendiri. Hal ini seperti yang terjadi dalam penggalan wacana berikut.

Kenapa manusia perlu agama? Karena manusia mempunyai kelemahan dan kekurangan. Kelemahan dan kekurangan manusia itu menumbuhkan nilai/ada kekuatan di balik kekuatan.

Penggalan teks di atas menyampaikan bahwa penutur atau dosen bertanya kepada mahasiswa (lawan tutur), namun kemudian karena penutur tidak sabar menunggu jawaban dalam interaksinya, akhirnya, pertanyaan itu pun dijawab dengan sendirinya. Ia berperan sebagai penanya sekaligus penjawab. Hal ini dapat menghilangkan peluang untuk lawan 
bicaranya mengemukakan jawaban yang berupa argumentatif.

Salah satu fungsi dosen ialah sebagai penilai. Untuk menjalankan fungsi penilain tersebut, dosen harus mengajukan pertanyaan-pertanyaan kepada mahasiswanya. Pertanyaan-pertanyaan itu hendaknya pertanyaan-pertanyaan yang dapat menstimulasi mahasiswa untuk berfikir. Kenyataan yang terjadi di dalam proses perkuliahan di kelas tersebut ialah pertanyaan-pertanyaan yang diajukan dosen hanya sekedar pertanyaan pada tingkat kongnitif yang menginginkan mahasiswa mereproduksi ingatannya.

Pertanyaan memang dapat digunakan untuk memulai percakapan dan dapat digunakan berkali-kali. Peran penting pertanyaan adalah untuk memunculkan jawaban dan sekaligus menjaga agar percakapan berangsung. Oleh sebab itu, dosen memunculkan lagi pertanyaan tentang fakta yang berkaitan materi yang pernah dan sedang dibahasnya.

Kalaupun ada pertanyaan yang meminta mahasiswa berpikir secara mendalam, misalnya pertanyaan mengapa dan bagaimana, jawabanya akan sama dengan kasus pertanyaan yang memunculkan kata apa (what), siapa (who), di mana (where), dan kapan (when). Jadi, mahasiswa kurang diberi stimulasi untuk mengeksplorasi kemampuannya dalam hal bernalar. Hal ini ditemukan pada pertanyaan. Dengan kata tanya mengapa mahasiswa sebenarnya sudah diajak untuk mengemukakan alasan, namun dosen tampaknya tidak sabar menunggu dan cepat menyela jawaban mahasiswa. Mahasiswa merasa belum lengkap jawabannya dan menyambungi jawabannya dosen langsung menyela dan mahasiswa menjawab. Dosen kemudian mengulang kembali jawaban mahasiswa agar kelas mendengar secara utuh jawaban mahasiswa tersebut dan meminta mahasiswa secara serempak mengikuti jawaban dengan cara menaikkan intonasi ujarannya pada ujung ujaran sehingga secara otomatis mahasiswa mengikuti ujung ujaran dosen.

Pada sisi lain, perilaku dosen yang memberikan kesempatan bagi mahasiswa untuk mengeksplorasi kemampuan yang dimiliki mahasiswa merupakan pengejawantahan perubahan pradigma fungsi dosen dalam masyarakat. Di tengah perjalanan perkuliahan tampaknya dosen mengubah struktur intraksi yang telah dilakukannya. Dosen memikirkan cara agar mahasiswa berpartisispasi dengan memandu sistem pergilirn berbicara. Dosen memberikan kesempatan kepada kepada mahasiswanya untuk membuat pertanyaan dengan mengunakan serangkaian kata Tanya yaitu $5 \mathrm{~W} 1 \mathrm{H}$. 
dengan membuat pertanyaan dan jawaban terhadap pertanyaan yang dibuat oleh mahasiswa itu sendiri dosen melakukan pemberdayaan terhadap mahasiswa. Jadi, setiap mahasiswa diminta membuat pertanyaan dan jawabannya dan mahasiswa diminta maju berpasangan ke depan kelas.

Tugas mahasiswa pertama menanyakan mahasiswa kedua dan mahasiswa kedua harus dapat menjawab pertanyaan yang diajukan mahasiswa pertama. Mahasiswa pertama sekaligus sebagai penilain mahasiswa kedua (peer editing). Dalam hal ini, dosen berlaku hanya sebagai fasilitator dan motivator. Pada aktivitas tersebut, dosen tidak lagi sebagai penyampai tunggal materi perkuliahan. Peran dosen sebagai otoritas tunggal pengembang materi diganti oleh mahasiswanya.

Pemberdayaan mahasiswa sangat diperlukan dalam proses pebelajran. Hal ini mulai dirasakan oleh dosen kelas tersebut setelah proses perkuliahan berlangsung setengah jalan. Selain pola penggiliran yang dikemukakan di atas, dosen mulai mengubah strategi yang diterapkannya.

Dari data tuturan dosen tersebut, terdapat empati dosen terhadap aktivitas yang dilakukan mahasiswa dengan memunculkan backchannelling, seperti ya, bagus, benar, dan sebagainya. Hal ini pertanda bahwa dosen menunjukan perhatiannya terhadap pekerjaan yang dilakaukan mahasiswa. Namun pada sisis lain, tampaknya terhadap prilaku ganda pada diri dosen. Hal ini dapat dilihat dari tidak adanya reaksi apa pun, baik verbal maupun nonverbal ketika mahasiswa beraktivitas.

\section{Penutup}

Berdasarkan beberapa uraian pada bagian pembahasan, peneliti dapat menarik simpulan sebagai berikut.

1) Situasi tutur kuasa bahasa dalam wacana perkuliahan di FSEI IAIN Pontianak dapat digambarkan bahwa saat penutur menyampaikan tuturannya situasi menjadi lebih tenang dan mendapatkan perhatian yang optimal dari lawan tutur. Sementara situasi lawan tutur saat memberikan tuturan cenderung tidak mendapatkan fokus perhatian dari penutur (dosen).

2) Pada dimensi sosial yang terjadi dalam kuasa wacana interaksi dalam perkuliahan di FSEI IAIN Pontiana, ditemukan sejumlah praktik sosial yang mengambarkan adanya hegomini dosen terhadap mahasiswa. Terdapat pula praktik pemunculan otoritas dosen baik, sebagai pengatur disiplin maupun sebagai pemberi materi. Ada pula dominasi dosen di dalam perkuliahan 
dan juga dosen menjadi orang yang serba tahu.

Selain itu, terdapat pula ketidakkonsistenan dosen dalam praktik prilakunya di depan perkuliahan. Di satu sisi, dosen mengiginkan jawaban yang mendalam ketika mahasiswa menjawab pertanyaan, di sisi lain dosen menunjutkan ketidaksabarannya menunggu mahasiswa menjawab.

Pada sisi lain, terdapat perubahan perilaku pada pertengahan proses pembelajaran. Dosen mengubah fungsinya dalam koridor paradigma konvensional ke paradigma nonkonvensional. Dosen mengubah struktur intraksi ke dalam perkuliahan. Dosen mulai memberdayakan mahasiswanya. Dengan demikian, dosen lebih banyak berlaku sebagai fasilitator dan motivator.

\section{Daftar Pustaka}

Isnaini, Yulainti. 2012. Kekuatan Bahasa dalam Publik Speaking sebagai Penunjan Keberhasilan Belajar. Prosiding Seminar Internasional. Mataram; Unramb Press. 2012, Hlm.199.

Ika Wahyu Prasetya. 2013. Analisis Kesalahan Berbahasa Tuturan Mahasiswa dalam Seminar Proposal Skripsi Mahasiswa. Pancaran. Vol. 2. No. 2. Halman 11.

Khak, M. Abdul. 2015. Formula Kuasa dalam Bahasa Surat Kabar: Analisis
Dimensi Mikro AWK Model Fairclough. Metalingua, Vol. 13 No. 1, Juni 2015:39-50.

Kridalaksana, Harimurti. 2007. Pembentukan Kata dalam Bahasa Indonesia. Jakarta: Gramedia.

Putrayasa, Ida Bagus. 2009. Tatat Kalimat Bahasa Indonesia. Bandung: Refika Aditama.

Maftuhin, Arif. 2017. INKLUSI: Journal of Disability Studies, Vol. 4, No. 2, Jul-Des 2017.

Mastoyo, Tri. 2007. Pengantar Metode Penelitian Bahasa. Yogyakarta: Carasvati Book.

Munfarida, Elya. 2014. Analisis Wacana Kritis dalam Perspektif Norman Fairclough. Komunika, Vol. 8, No. 1, Januari-Juni 2014.

Ramlan. 2008. Kalimat, Konjungsi, dan Preposisi Bahasa Indonesia dalam Penulisan Karangan Ilmiah. Yogyakarta. Sanata Darma Press.

Subroto, Edi. 2007. Pengantar Metode Penelitian Linguistik Struktural. Surakarta: UNS Press.

Samsuri. 1991. Analisis Bahasa: Memahami Bahasa Secara Ilmiah. Jakarta: Erlangga.

Sultan. 2013. Klirumologi Bahasa Indonesia. Pontianak: STAIN Press

Soedjito, Djoko Saryono. 2012. Tata Kalimat Bahasa Indonesia. Malang: Aditiya Media.

Sunda Ariana. 2012. Kesalahan Penggunaan EYD dalam Karya Ilmiah Dosen Universitas Bina Darma. 
Tarigan. 1997. Analisi Bahasa. Jakarta: Gramedia.

Coulthard, M. 1977. An Introduction to Discourse Analysis. Harlow: Longman Group Limited.

Creswell, Jonh W. 1998. Qualitative Inquiry and Research Desing: Choosing Among five Traditions. Thousand Oaks: Sage Publications.

Eriyanto. 2001. Analisis Wacana: Pengantar Analisis Teks Media. Yogyakarta: LkiS

Fairclough, N. 1995. Critical Discourse Analysis: The Critical Study of Language. London: Longman.

Indrawati, Sri. 2003. Pola Pertukaran dalam Wacana Intraksi Perkuliahan. Lingua: Jurnal Bahasa dan Sastra. Vol. 5, No. 1 Desember 2003.

Jorgensen, Marianne W. dan Louise J. Phillips. 2007. Analisis Wacana. Teori dan Metode (Terjemahan). Yogyakarta: Pustaka Pelajar.

McCarthy, M. 1991. Discourse Analysis for Language Teachers. Cambridge: Cambidge Uniersity Press.

Purnomo, Maslathif Dwi. 2017. The Power of Language (Kuasa Bahasa) Dalam Dimensi Sosial, Politik, Budaya, dan Pendidikan. Yogyakarta: Naila Pustaka

Purnomo, Mulyadi Eko. 2003. Analisis Wacana Kritis dan Penerapannya. Lingua: Jurnal Bahasa dan sastra. Vol.5, No. 1 Desember 2003.

Saraswati, Ardhina dan Ni Wayan Sartini. 2017. Wacana Perlawanan Persebaya 1927 terhadap PSSI: Analisis Wacana Kritis Norman Fairclough.
Jurnal Mozaik Humaniora. Vol. 17 (2):181-191. Desember 2017.

Stenstrom, Anna-Brita. 1994. An Introduction to Spoken Intraction. London: Longman.

Struever, N. S. 1985. Historical Discourse. Handbook of Discourse Analysis. Dalam Teun A. Van Dijk (Ed.) London: Academic press. Vol. 1. 
136 | Mabasan, Vol. 13, No. 2, Desember 2019, hlm. 111-136

p-ISSN: 2085-9554, e-ISSN: 2621-2005 